\title{
Comparative study of oral and vaginal misoprostol for cervical priming prior to first trimester suction evacuation
}

\author{
Ekanath Latha $^{1,2} *$, Reddi Rani ${ }^{1}$ \\ ${ }^{1}$ Department of Obstetrics \& Gynaecology, JIPMER, Pondicherry, India \\ ${ }^{2}$ Presently as Assistant Professor, Department of Obstetrics \& Gynaecology, IGMCRI, Pondicherry, India
}

Received: 25 September 2013

Accepted: 8 October 2013

*Correspondence:

Dr. Ekanath Latha,

E-mail: drlathaanand @gmail.com

(C) 2013 Latha E et al. This is an open-access article distributed under the terms of the Creative Commons Attribution Non-Commercial License, which permits unrestricted non-commercial use, distribution, and reproduction in any medium, provided the original work is properly cited.

\section{ABSTRACT}

Background: To compare the effectiveness of vaginal with oral misoprostol as a cervical ripening agent prior to first trimester suction evacuation and to compare side effects.

Methods: Hundred and fifty one women opting for medical termination of pregnancy in first trimester were randomized to receive $400 \mu \mathrm{g}$ oral and vaginal misoprostol. Suction evacuation was carried out 3 to 4 hours after misoprostol. Results were analyzed.

Results: Products of conception were noted in $15.8 \%$ of patients in vaginal group compared to only $5.3 \%$ of patients in the oral group. $89.4 \%$ of patients in vaginal group had dilatation of $\geq 7$ Hegar's compared to $58.6 \%$ in oral group. Additional dilatation was required in $69.3 \%$ in oral group compared to $38.1 \%$ patients in vaginal group; all these results being statistically significant. Adverse effects were noted in $50.7 \%$ of patients in oral group and $25 \%$ of patients in vaginal group.

Conclusion: Comparing the oral and vaginal route of $400 \mu \mathrm{g}$ of misoprostol 3 to 4 hours before suction evacuation, it was observed that vaginal route is associated with better results and fewer side effects.

Keywords: Oral misoprostol, Vaginal misoprostol, Cervical priming

\section{INTRODUCTION}

Suction evacuation is still the method of choice for terminating late first trimester unwanted pregnancies. The procedure requires dilatation of cervix and evacuation, which is not always safe and is associated with cervical injury, uterine perforation, hemorrhage, infection and cervical incompetence. ${ }^{1}$ To reduce these complications, cervical priming prior to surgical termination is necessary. ${ }^{2}$

A number of effective methods for cervical priming are available. Osmotic dilators are associated with increased risk of infection and displacement. Mifepristone though effective is expensive. Prostaglandin E2 analogues dinoprostone gel and 15- methyl F2 $\alpha$ are expensive, unstable and requires refrigeration. $\mathrm{PGE}_{1}$ analogues misoprostol and gemeprost are found to be good ripening agents. Gemeprost is expensive, relatively unstable and requires refrigeration for storage. Misoprostol has established a lead in terms of availability, ease of administration, cost and effectiveness.

The present study is undertaken to compare the efficacy of vaginal with oral misoprostol as a cervical ripening agent before first trimester surgical evacuation.

\section{METHODS}

The study was a prospective randomized comparative study conducted in department of Obstetrics and Gynaecology, JIPMER after obtaining ethical committee approval.

Hundred and fifty one women opting for medical termination of pregnancy in first trimester were 
randomized using random number table to receive oral or vaginal misoprostol. 76 women received vaginal misoprostol and 75 received oral misoprostol 3 to 4 hours before suction evacuation. Informed consent was taken from all women.

Inclusion criterion was women with viable intrauterine pregnancy less than 12 weeks opting for medical termination of pregnancy.

Exclusion criteria were: anemia $(\mathrm{Hb}<8 \mathrm{~g} \%)$, threatened abortion, previous caesarean section, any contraindication to prostaglandins like asthma, hypertension etc.

Pre operative bleeding if any was noted. The severity of abdominal pain experienced pre operatively was assessed by using a three point response scale: no pain, minimal or moderate pain requiring no analgesics and severe pain requiring analgesics. The presence or absence of other pre operative complications like fever, nausea and vomiting, diarrhoea were noted.

Suction evacuation was carried out under general or regional anaesthesia. The presence or absence of products of conception at the cervical os or vagina was noted. The degree of cervical dilatation achieved was assessed by passing Hegar's dilator. The size of the largest dilator that could be passed into the cervix without resistance was recorded as the amount of cervical dilatation achieved. A pre operative cervical dilatation of $7 \mathrm{~mm}$ was considered satisfactory. Ease of dilatation was subjectively graded as easy, moderate or difficult. Amount of additional dilatation required was noted. Intra operative blood loss was assessed. Any other intra and post operative complications were noted. Blood pressure, pulse rate, temperature, side effects like abdominal pain, nausea, vomiting, diarrhea and fever were recorded pre and post operatively. Post operative haemoglobin was assessed in all women. Statistical analysis was done using chi square test and $\mathrm{t}-$ test.

\section{RESULTS}

\section{Patient characteristics}

Age distribution was similar in both groups. Majority of patients in either group were between 21 to 30 years. 93.3\% patients in oral group and $85.5 \%$ in vaginal group were gravida 3 or more. 10 patients in either group had spontaneous abortions.

$72 \%$ patients in oral group and $67 \%$ in vaginal group had gestational age between 43 and 70 days. The most common indication for MTP was unwanted pregnancy due to social reasons in both groups. Concurrent sterilization was done in $90.8 \%$ patients in oral group and $90.7 \%$ in vaginal group. There were 4 cases of unmarried pregnancy in oral group and 5 in vaginal group. The patient characteristics are shown in table 1 .
Table 1: Patient characteristics.

\begin{tabular}{|lll|}
\hline Characteristic & $\begin{array}{l}\text { Oral } \\
(\mathbf{N}=75)\end{array}$ & $\begin{array}{l}\text { Vaginal } \\
(\mathbf{N}=76)\end{array}$ \\
\hline Mean age (years) & 27.33 & 26.64 \\
\hline Gravidity $\geq 3$ & $70(93.3)$ & $65(85.5)$ \\
\hline Parity $\geq 2$ & $68(90.7)$ & $65(85.5)$ \\
\hline Previous abortion & $11(14.6)$ & $13(17)$ \\
\hline Gestational age (days) & 62.5 & 64.14 \\
\hline
\end{tabular}

\section{Parameters}

Mean priming time was 216.2 minutes ( $3 \mathrm{hrs} 36 \mathrm{~min}$ ) in oral group and 210 minutes (3hrs $30 \mathrm{~min}$ ) in vaginal group, which was not statistically significant.

Products of conception were noted in $12(15.8 \%)$ patients in vaginal group and $4(5.3 \%)$ patients in oral group. This was found to be statistically significant $(\mathrm{p}=0.037)$.

Sixty eight patients $(89.4 \%)$ in the vaginal group had a satisfactory cervical dilatation compared to 44 patients $(58.6 \%)$ in the oral group. This was also found to be statistically significant $(\mathrm{p}=0.0003)$. Additional dilatation was required in 52 patients $(69.3 \%)$ in oral group compared to 29 patients $(38.1 \%)$ in vaginal group which was also statistically significant $(\mathrm{p}=0.0003)$.

Dilatation was easy in 72 patients $(94.7 \%)$ in vaginal group compared to $54(72 \%)$ in the oral group. $(\mathrm{p}=0.001)$. The mean evacuation time and amount of bleeding did not statistically differ in either group.

The parameters analyzed are shown in table 2 .

Table 2: Parameters.

\begin{tabular}{|c|c|c|c|c|}
\hline \multirow{2}{*}{ Parameter } & $\begin{array}{l}\text { Oral } \\
(\mathbf{N}=75)\end{array}$ & $\begin{array}{l}\text { Vaginal } \\
(\mathrm{N}=76)\end{array}$ & \multirow{2}{*}{ P Value } & \multirow{2}{*}{ S/NS } \\
\hline & $\mathbf{N}(\%)$ & $\mathbf{N}(\%)$ & & \\
\hline $\begin{array}{l}\text { Priming time } \\
\text { (minutes) }\end{array}$ & 216.2 & 210 & 0.519 & NS \\
\hline \multicolumn{5}{|l|}{ Products at os } \\
\hline Absent & $71(94.7)$ & $64(84.2)$ & \multirow{2}{*}{0.037} & \multirow{2}{*}{$\mathrm{S}$} \\
\hline Present & $4(5.3)$ & $12(15.8)$ & & \\
\hline \multicolumn{5}{|c|}{ Dilatation achieved (Hegar's size) } \\
\hline$<7$ & $31(41.3)$ & $8(10.5)$ & \multirow{3}{*}{0.0003} & \multirow{3}{*}{$\mathrm{S}$} \\
\hline 7 to 9 & $36(48)$ & $53(69.7)$ & & \\
\hline$\geq 10$ & $8(10.6)$ & $15(19.7)$ & & \\
\hline
\end{tabular}




\begin{tabular}{|c|c|c|c|c|}
\hline Not required & $23(30.7)$ & 47 (61.9) & \multirow{2}{*}{0.0003} & \multirow{2}{*}{$\mathrm{S}$} \\
\hline Required & $52(69.3)$ & $29(38.1)$ & & \\
\hline \multicolumn{5}{|l|}{ Ease of dilatation } \\
\hline Easy & $54(72)$ & $72(94.7)$ & \multirow{3}{*}{0.001} & \multirow{3}{*}{$\mathrm{S}$} \\
\hline Moderate & $18(24)$ & $4(5.3)$ & & \\
\hline Difficult & $3(4)$ & $0(0)$ & & \\
\hline $\begin{array}{l}\text { Evacuation time } \\
\text { (minutes) }\end{array}$ & 8.48 & 7.18 & 0.079 & NS \\
\hline $\begin{array}{l}\text { Amount of } \\
\text { bleeding }(\mathrm{ml})\end{array}$ & 34.4 & 28.68 & 0.096 & NS \\
\hline
\end{tabular}

S - Significant; NS - Nonsignificant

Adverse effects were noted in 38 patients $(50.7 \%)$ in the oral group and 19 patients $(25 \%)$ in the vaginal group. This was statistically significant. $(\mathrm{p}=0.001)$. The most common adverse effects were abdominal pain followed by pain and bleeding.

There were 2 cases of uterine perforation in the vaginal group - one was a case of bicornuate uterus and other acutely retroverted uterus, both of them not related to application of misoprostol. None of them had post op infection.

The adverse effects are shown in table 3.

Table 3: Adverse effects.

\begin{tabular}{|c|c|c|c|c|c|c|}
\hline \multirow{2}{*}{$\begin{array}{l}\text { Adverse } \\
\text { Effect }\end{array}$} & \multicolumn{2}{|c|}{$\begin{array}{l}\text { Oral } \\
(\mathrm{N}=75)\end{array}$} & \multicolumn{2}{|c|}{$\begin{array}{l}\text { Vaginal } \\
(\mathrm{N}=76)\end{array}$} & \multirow{2}{*}{$\begin{array}{l}\mathbf{P} \\
\text { value }\end{array}$} & \multirow{2}{*}{ S/NS } \\
\hline & $\mathbf{N}$ & $\%$ & $\mathbf{N}$ & $\%$ & & \\
\hline Absent & 37 & 49.3 & 57 & 75 & \multirow{2}{*}{0.001} & \multirow{2}{*}{$S$} \\
\hline Present & 38 & 50.7 & 19 & 25 & & \\
\hline Abdominal & 34 & 45 & 10 & 13 & & \\
\hline
\end{tabular}

\begin{tabular}{|lllll|}
\hline Pain & & & & \\
\hline $\begin{array}{l}\text { Pain }+ \\
\text { Bleeding }\end{array}$ & 3 & 4 & 9 & 12 \\
\hline Nausea & 1 & 1 & 0 & 0 \\
\hline Vomiting & 0 & 0 & 0 & 0 \\
\hline Diarrhoea & 0 & 0 & 0 & 0 \\
\hline Fever & 0 & 0 & 0 & 0 \\
\hline
\end{tabular}

\section{S - Significant; NS - Nonsignificant}

\section{DISCUSSION}

Cervical ripening before evacuation of the uterus can reduce complications of cervical injury, uterine perforation, haemorrhage and incomplete evacuation of the uterus.

In our study, the mean age of women in oral group was 27.37 years and 26.64 in vaginal group. Most of them were multiparous women. The mean gestational age was 62.52 days in oral group and 64.14 days in vaginal group. The mean priming time was 216.2 minutes ( $3 \mathrm{hrs} 36 \mathrm{~min}$ ) in oral group and 210 minutes $(3 \mathrm{hrs} 30 \mathrm{~min})$ in vaginal group. Studies by Lawrie et $\mathrm{al}^{3}$ and Oppegaard et $\mathrm{al}^{4}$ had a priming time of 2 to 4 hours for vaginal misoprostol compared to 12 hours for oral misoprostol and the difference in dilatation achieved was not statistically significant.

Oppegaard et al reported based on several studies a consensus has emerged that optimal treatment regimen to use is $400 \mu \mathrm{g}$ misoprostol 3 to 4 hours preoperatively; with vaginal administration superior to oral administration. ${ }^{4}$

A comparison of dilatation achieved with various doses of misoprostol and priming time is shown in table 4.

Table 4: Comparison of dilatation achieved with misoprostol in various studies.

\begin{tabular}{|c|c|c|c|c|c|c|c|c|c|}
\hline \multirow{2}{*}{ Study } & \multicolumn{4}{|c|}{ Oral misoprostol } & \multicolumn{4}{|c|}{ Vaginal misoprostol } & \multirow{2}{*}{$\begin{array}{l}\text { P value } \\
\text { S/NS }\end{array}$} \\
\hline & No. & Dose & $\begin{array}{l}\text { Priming } \\
\text { time }\end{array}$ & $\begin{array}{l}\text { Dilatation } \\
(\mathrm{mm})\end{array}$ & No. & Dose & $\begin{array}{l}\text { Priming } \\
\text { time }\end{array}$ & $\begin{array}{l}\text { Dilatation } \\
(\mathbf{m m})\end{array}$ & \\
\hline Lawrie et al (1996) ${ }^{3}$ & 30 & $400 \mu \mathrm{g}$ & 12 hours & 6.91 & 30 & $800 \mu \mathrm{g}$ & 2 to 4 hours & 6.99 & NS \\
\hline MacIsaac et al (1999) ${ }^{6}$ & 45 & $400 \mu \mathrm{g}$ & 4 hours & 24.2 & 47 & $400 \mu \mathrm{g}$ & 4 hours & 28 & $<0.05 \mathrm{~S}$ \\
\hline Carbonell et al (2001) ${ }^{7}$ & 450 & $400 \mu \mathrm{g}$ & 8 hours & 8.1 & 450 & $400 \mu \mathrm{g}$ & 4 hours & 8.5 & $0.0001 \mathrm{~S}$ \\
\hline Sharma et al (2005) ${ }^{5}$ & 30 & $400 \mu \mathrm{g}$ & 1 hour & 7.4 & 30 & $800 \mu \mathrm{g}$ & 1 hour & 6.6 & NS \\
\hline Oppegaard et al (2006) ${ }^{4}$ & 169 & $400 \mu \mathrm{g}$ & 12 hours & 6.2 & 169 & $400 \mu \mathrm{g}$ & 2 to 4 hours & 6.5 & NS \\
\hline Present study & 75 & $400 \mu \mathrm{g}$ & $\begin{array}{l}3 \text { to } 4 \\
\text { hours }\end{array}$ & 6.95 & 76 & $400 \mu \mathrm{g}$ & 3 to 4 hours & 8.32 & $0.0003 \mathrm{~S}$ \\
\hline
\end{tabular}

S - Significant; NS - Nonsignificant 
Sharma et al in their study involving 60 women randomized to receive $400 \mu \mathrm{g}$ of misoprostol in the oral group and $800 \mu \mathrm{g}$ in the vaginal group found no priming effect in the mean baseline cervical dilatation $(p=0.16)$ between the oral and vaginal groups when the priming time was one hour and concluded that the time required to achieve effective cervical priming exceeds one hour. ${ }^{5}$

MacIssac et al in their randomized controlled trial comparing oral misoprostol $(400 \mu \mathrm{g})$, vaginal misoprostol $(400 \mu \mathrm{g})$ and laminaria tents in 106 women at 7 to 14 weeks gestation, administered 4 hours prior to suction evacuation found significantly greater mean dilatation in vaginal group than oral group $(\mathrm{p}<0.05)$ concluding that vaginal misoprostol was superior to oral misoprostol and is an acceptable mode for cervical dilatation before surgical abortion which is inexpensive, easy to administer and achieves equal or greater dilatation with less pain. ${ }^{6}$

Our study showed similar results with mean dilatation of $8.32 \mathrm{~mm}$ in the vaginal group compared to $6.95 \mathrm{~mm}$ in oral group which was statistically significant with a priming time of 3 to 4 hours.

Additional dilatation was easy in vaginal group which was comparable to study by MacIssac et al ${ }^{6}$. In their study, women who received vaginal misoprostol had greater mean dilatation and extra dilatation needed was easier in this group

Adverse effects were noted in $50.7 \%$ patients in vaginal group compared to $25 \%$ in the oral group; the commonest side effect being abdominal pain. Carbonell et al in their study reported that the frequencies of side effects such as nausea, vomiting, diarrhoea and chills were 10, 8, 18, 4 times lower respectively with vaginal misoprostol group than oral group. ${ }^{7}$

\section{CONCLUSION}

Comparing the oral and vaginal route of $400 \mu \mathrm{g}$ of misoprostol 3 to 4 hours before suction evacuation, it was observed that vaginal route is associated with better dilatation and additional dilatation was also easier with fewer side effects.
Funding: None

Conflict of interest: None

Ethical approval: Approved by the institutional ethical committee

\section{REFERENCES}

1. Ashok PW, Hamoda H, Nathani F, Flett GMM, Templeton A. Randomized controlled study comparing oral and vaginal misoprostol for cervical priming prior to surgical termination of pregnancy. British Journal of Obstetrics and Gynaecology 2003; 110: 1057 - 1061 .

2. Bugalho A, Bique C, Almeida L, Bergstrom S. Application of vaginal misoprostol before cervical dilatation to facilitate first trimester pregnancy interruption. Obstetrics and Gynecology 1994; 83: $729-731$.

3. Lawrie A, Penney G, Templeton A. A randomized comparison of oral and vaginal misoprostol for cervical priming before suction termination of pregnancy. British Journal of Obstetrics and Gynaecology 1996; 103: 1117 - 1119.

4. Oppegaard KS, Qvigstad E, Nesheim BI. Oral versus self-administered vaginal misoprostol at home before surgical termination of pregnancy: a randomized controlled trial. British Journal of Obstetrics and Gynaecology2006; 113: 58-64.

5. Sharma S, el Refaey H, Stafford M. Oral versus vaginal misoprostol administered one hour before surgical termination of pregnancy: a randomized controlled trial. British Journal of Obstetrics and Gynaecology 2005; 112: 456-460.

6. Macisaac L, Grossman D, Balistreri E, Darney P. A randomized controlled trial of laminaria, oral misoprostol, and vaginal misoprostol before abortion. Obstetrics and Gynecology 1999; 93: 766770 .

7. Carbonell JL, Velazco A, Rodriguez Y. Oral versus vaginal misoprostol for cervical priming in firsttrimester abortion: a randomized trial. European Journal of Contraception and Reproductive Health Care 2001; 6(3): 134-140.

DOI: $10.5455 / 2320-1770 . i j r \operatorname{cog} 20131216$

Cite this article as: Latha E, Rani R. Comparative study of oral and vaginal misoprostol for cervical priming prior to first trimester suction evacuation. Int J Reprod Contracept Obstet Gynecol 2013;2:573-6. 